\title{
Anesthetic potential of the essential oils of Lippia alba and Lippia origanoides in Tambaqui juveniles
}

\author{
Hugo Napoleão Pereira da Silva ${ }^{1}$ (D) Brenna Celina Ferreira de Carvalho ${ }^{2}$ \\ Janna Laely dos Santos Maia ${ }^{2}$ Alexssandro Geferson Becker ${ }^{3}$ (D) Bernardo Baldisserotto ${ }^{4}$ (D) \\ Berta Maria Heinzmann $^{5}$ Rosa Helena Veras Mourão ${ }^{6}$ Lenise Vargas Flores da Silva ${ }^{2^{*}}$
}

\footnotetext{
${ }^{1}$ Programa de Pós-graduação em Biodiversidade Animal, Departamento de Fisiologia e Farmacologia, Universidade Federal de Santa Maria (UFSM), Santa Maria, RS, Brasil.

${ }^{2}$ Universidade Federal do Oeste do Pará (UFOPA), Instituto de Ciências e Tecnologia das Águas (ICTA), 68040-470, Santarém, PA, Brasil. E-mail: lvfrsi@yahoo.com. *Corresponding author.

${ }^{3}$ Departamento de Zootecnia, Setor de Palotina, Universidade Federal do Paraná (UFPR), Palotina, PR, Brasil.

${ }^{4}$ Programa de Pós-graduação em Zootecnia, Departamento de Fisiologia e Farmacologia, Universidade Federal de Santa Maria (UFSM), Santa Maria, RS, Brasil.

${ }^{5}$ Departamento de Farmácia Industrial, Universidade Federal de Santa Maria (UFSM), Santa Maria, RS, Brasil.

${ }^{6}$ Laboratório de Bioprospecção e Biologia Experimental, Universidade Federal do Oeste do Pará (UFOPA), Santarém, PA, Brasil.
}

ABSTRACT: The aim of this study was to investigate the anesthetic effect of the essential oils (EOs) of Lippia alba (citral and linalool chemotypes, EOLA-C and EOLA-L respectively) and Lippia origanoides (chemotype carvacrol, EOLO-Ca) on tambaqui (Colossoma macropomum) juveniles. The tested concentrations of the L. alba and L. origanoides EOs were: 25, 50, 100, and 200 $\mu L / L$. Time required to reach the stages of sedation, deep anesthesia, and recovery, as well as ventilatory frequency, were monitored for each EO concentration. The results indicated that all EO concentrations tested induced tambaqui anesthesia and that the ventilatory frequency was altered by the EOs. $L$. origanoides showed the shortest time to induce sedation and anesthesia, but had long recovery times. L. alba EO (citral $100 \mu L / L$ and linalool $200 \mu \mathrm{L} / \mathrm{L}$ ) can be used to efficiently anaesthetise tambaqui juveniles with an efficient recovery.

Key words: anaesthesia, carvacrol, citral, linalool, ventilatory frequency.

Potencial anestésico do óleo essencial de Lippia Alba e Lippia origanoides em juvenis de Tambaqui

RESUMO: $O$ objetivo deste estudo foi investigar o efeito anestésico dos óleos essenciais (EOs) de Lippia alba (quimiotipos citral e linalool - EOLA-C e EOLA-L respectivamente) e Lippia origanoides (quimiotipo carvacrol-EOLO-Ca) em juvenis de tambaqui (Colossoma macropomum). As concentrações testadas dos EOs de L. alba e L. origanoides foram: 25, 50, 100 ou $200 \mu L / L$. O tempo para atingir os estágios de sedação, anestesia profunda, recuperação e frequência ventilatória foram monitorados em cada concentração de EO. Os resultados indicam que todas as concentrações testadas dos OE induziram a anestesia do tambaqui e que a frequência ventilatória foi alterada pelos EOS. L. origanoides mostrou o tempo mais rápido para induzir sedação e anestesia, mas os tempos de recuperação foram longos. EO L. alba (citral $100 \mu \mathrm{L} / \mathrm{L}$ e linalol $200 \mu \mathrm{L} / \mathrm{L}$ ) pode ser utilizado como anestésico em juvenis de tambaqui, pela eficiência em anestesiar e recuperar. Palavras-chave: anestesia, carvacrol, citral, linalool, frequência ventilatória.

\section{INTRODUCTION}

The plants Lippia alba and Lippia origanoides (Verbenaceae) are widely reported in South America (HENNEBELLE et al., 2008; STASHENKO et al., 2010) and have several chemotypes (JULIÃO et al., 2003; STASHENKO et al., 2010; SOARES et al., 2017). The anesthetic efficacy of the essential oils (EOs) of the citral (EOLA-C) and linalool (EOLA-L) chemotypes of L. alba has been demonstrated in some species of freshwater fish, but response to the handling of sedated or anesthetized fish varied according to the species and chemotype (CUNHA et al., 2010; HOHLENWERGER et al., 2016; BECKER et al., 2018; SOUZA et al., 2018). Anesthetic efficacy of the EO of the carvacrol chemotype of $L$. origanoides (EOLO-Ca) has only been shown in the silver catfish Rhamdia quelen (BECKER et al., 2018). 
Tambaqui, Colossoma macropomum, is a freshwater fish reported in the Amazon and Orinoco River basins (SANTOS et al., 2009). It has been used as a Neotropical model to test the efficacy of anaesthetics obtained from plants (SACCOL et al., 2017; SILVA et al., 2017; BALDISSEROTTO et al., 2018; BATISTA et al., 2018). Recently, BATISTA et al. (2018) demonstrated that EOLA-C was an effective anesthetic for tambaqui, but the effects of EOLA-C and EOLA-L were not compared in this species in the same experiment. In addition, ventilatory frequency, which might provide an indication of changes in the metabolic rate (ALVARENGA \& VOLPATO, 1995), was also not tested in tambaqui anesthetized with these EOs. Therefore, the present study aimed to investigate the effects of EOLA-C, EOLA-L, and EOLO-Ca on the anesthesia of tambaqui juveniles, as well as on the ventilatory frequency of sedated and anesthetized fish.

\section{MATERIALS AND METHODS}

\section{Plant material, essential oils, and analysis}

Leaves of $L$. alba (EOLA-C) and $L$. origanoides (EOLO-Ca) were collected from an experimental field of the Universidade Federal do Oeste do Pará (UFOPA), Road Everaldo Martins (PA-457), km 26, municipality of Santarém, Pará State, Brazil, and leaves of L. alba (EOLA-L) were collected from the Universidade Federal de Santa Maria, campus Frederico Westphalen, Rio Grande do Sul state, Brazil. The percentages of the main compounds were: EOLA-C: $55.28 \%$ citral, EOLOCa: 47.20\% carvacrol (BECKER et al., 2018), and EOLA-L: $59.66 \%$ linalool (HELDWEIN et al., 2012).

\section{Fish conditions and experimental design}

Tambaqui juveniles $(1.4 \pm 0.5 \mathrm{~g}$ and $4.6 \pm 0.5$ $\mathrm{cm})$ were acquired from the Fish Production Station UAGRO Santa Rosa/SEDAP in Santarém, Pará, Brazil. Fish were under starve for $24 \mathrm{~h}$ prior to the experiments.

\section{Experiment 1}

Fish ( $\mathrm{n}=8$ for each concentration) were individually transferred to aquaria $(500 \mathrm{~mL})$ and exposed to $25,50,100$, or $200 \mu \mathrm{L} / \mathrm{L}$ of EOLA-C, EOLA-L, or EOLO-Ca. Each juvenile was used only once and was considered a replicate (total $n=96$ ). All EO concentrations were previously diluted in ethanol (1:9). Ethanol, at the highest concentration used to dilute the EOs $(1800 \mu \mathrm{L} / \mathrm{L})$, was also tested $(n=8)$. Induction times to sedation and deep anesthesia, as well as recovery time, were measured using a digital chronometer, and the maximum observation time was $30 \mathrm{~min}$. The anesthesia stages were characterized according to SMALL (2003). After induction, the fish were transferred to anesthetic-free aquaria to measure the anesthesia recovery time. The $\mathrm{pH}$, dissolved oxygen levels, temperature, conductivity, and total dissolved solids were measured during the experiment $\left(5.47 \pm 0.24, \quad 7.89 \pm 0.16 \quad \mathrm{mg} / \mathrm{L}, \quad 26.87 \pm 1.40 \quad{ }^{\circ} \mathrm{C}\right.$, $10.83 \pm 1.30 \mu \mathrm{S} / \mathrm{cm}$, and $5.40 \pm 0.54 \mathrm{mg} / \mathrm{L}$ respectively).

\section{Experiment 2}

Another group of tambaquis $(n=96)$ was exposed to the same EO concentrations reported above to determine the ventilatory frequency (VF) through sedation and deep anesthesia; this was obtained through a visual observation of 20 successive opercular or buccal movements (ALVARENGA \& VOLPATO, 1995).

\section{Statistical analyses}

All data are expressed as mean \pm standard error mean (SEM). Evaluation of the anesthetic activity was performed by regression analysis (concentration $\times$ time of anesthesia induction; concentration $\times$ time of recovery from anesthesia), using SigmaPlot version 11.0 (Systat software, Inc. Germany). Homogeneity of variances for the VF data was determined using a Levene's test; these data did not show homoscedasticity, and were then submitted to a Kruskal-Wallis ANOVA, followed by multiple comparisons of mean ranks for all groups using Statistica version 7.0 (Stat Soft, Tulsa, OK). The minimum significance level was set at $\mathrm{P}<0.05$.

\section{RESULTS}

Increasing the concentration of all EOs proportionally decreased the time required for sedation and deep anesthesia induction and increased the recovery time (Figure 1 and Table 1). Ethanol per se did not produce any anesthetic effect. There was no mortality from anesthesia induction within the tested range, or during recovery.

Fish exposed to EOLA-C showed higher $\mathrm{VF}$ values at $200 \mu \mathrm{L} / \mathrm{L}$ than those exposed to 50 $\mu \mathrm{L} / \mathrm{L}$ during the sedation stage. Tambaquis in deep anesthesia with EOLA-C presented the lowest VF at $50 \mu \mathrm{L} / \mathrm{L}$, followed by those at $100-200 \mu \mathrm{L} / \mathrm{L}$. Sedation with EOLA-L did not change the VF. The VF was significantly lower in fish anesthetized with EOLA-L at $100 \mu \mathrm{L} / \mathrm{L}$ than in those anesthetized with $25 \mu \mathrm{L} / \mathrm{L}$. Fish sedated with EOLO-Ca at $200 \mu \mathrm{L} / \mathrm{L}$ showed the highest VF, however during deep anesthesia, the fish only presented a significantly higher VF than those exposed to $50 \mu \mathrm{L} / \mathrm{L}$ (Table 2). 


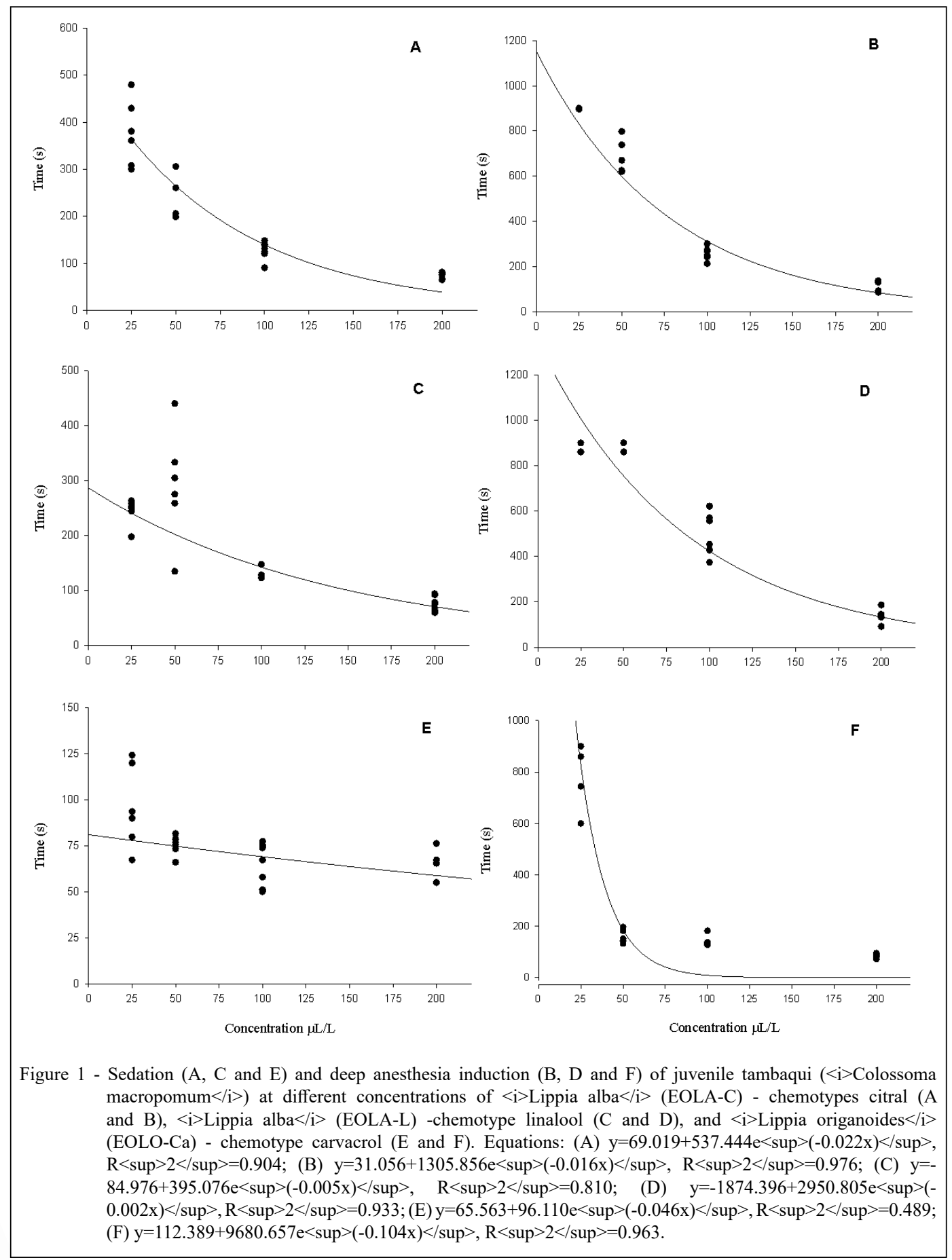

\section{DISCUSSION}

Tambaqui juveniles were sedated with the lowest EOLA-C and EOLA-L concentrations (25 $\mu \mathrm{L} / \mathrm{L}$ ) within approximately 6 and $4 \mathrm{~min}$, respectively; at $200 \mu \mathrm{L} / \mathrm{L}$, only approximately 2 min was needed to anesthetize this species. Similar findings have been reported in silver catfish sedated or anesthetized with EOLA-C with the same chemical composition (BECKER et al., 2018). However, BATISTA et al. (2018) reported a longer time to induce deep anesthesia with $200 \mu \mathrm{L} / \mathrm{L}$ EOLA-C in this species (almost $5 \mathrm{~min}$ ), 
Table 1 - Time required for induction of and recovery from anesthesia in tambaqui, Colossoma macropomum, exposed to the essential oils of Lippia alba: EOLA-C (chemotype citral) and EOLA-L (chemotype linalool), and Lippia origanoides: EOLO-Ca (chemotype carvacrol).

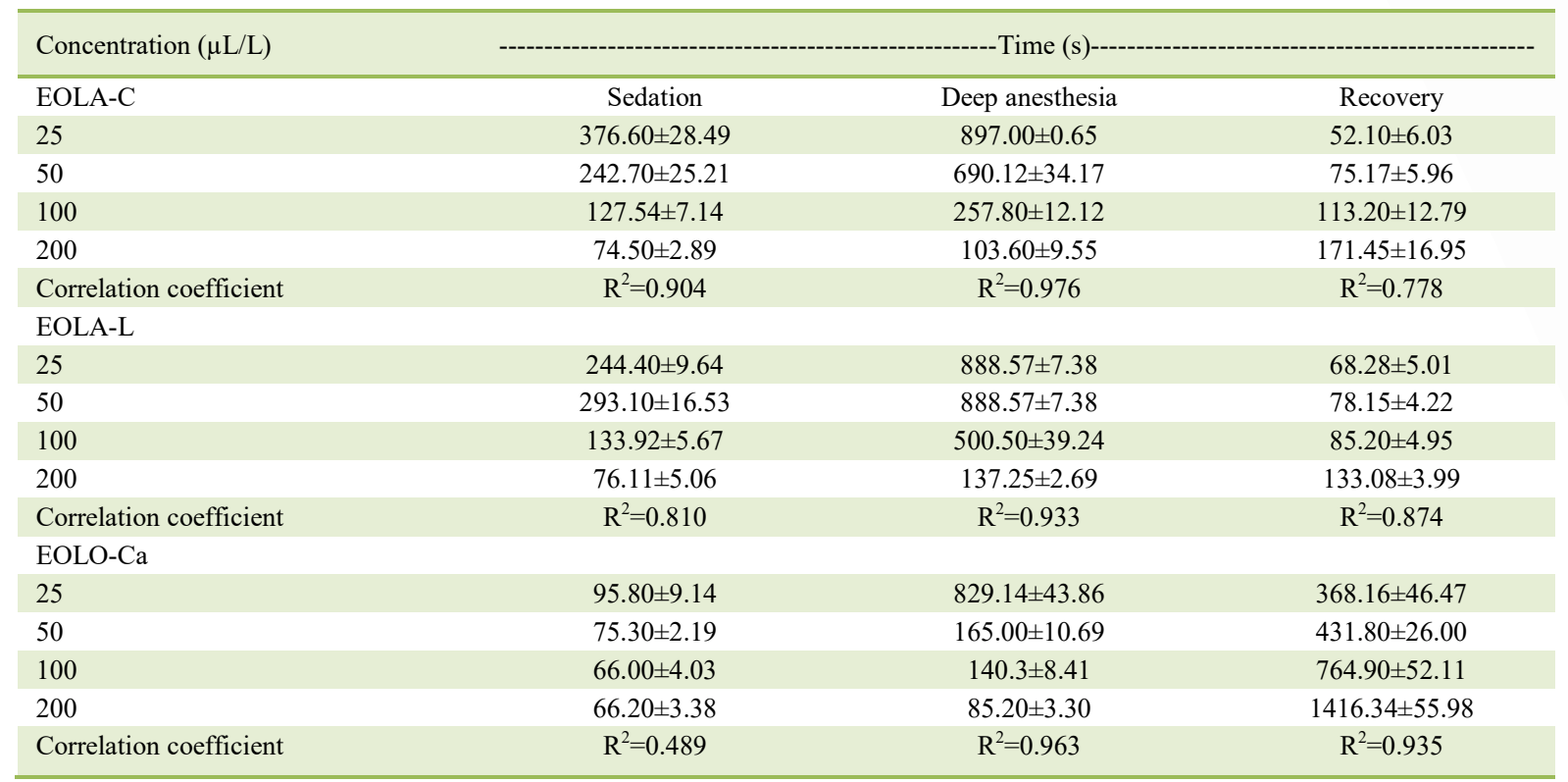

which is likely due to the composition of EOLA-C being different to that of the EOLA-C used in the current study (42 vs. $55.28 \%$ citral). Chemical composition of essential oils can change according to season, location, type of cultivation, and circadian cycle (CASTRO et al., 2002, RIBEIRO et al., 2018). Interestingly, the hybrid tambacu (Piaractus mesopotamicus males $\times$ tambaqui females) only reached deep anesthesia with EOLA-L (47.66\% linalool) at a concentration of $75 \mu \mathrm{L} / \mathrm{L}$ in approximately $5.5 \mathrm{~min}$, however time to induce deep anesthesia was a little longer than 1 min at $200 \mu \mathrm{L} / \mathrm{L}$ (SENA et al., 2016). This difference to the present study could be related to the species and/or the percentage of compounds in EOLA-L (e.g. 59.66\% linalool). The EO of Aniba rosaeodora (EOAR), which contains $82 \%$ linalool, was faster to anesthetize tambaqui than the linalool extracted from this EO, demonstrating that some minor compounds might contribute to improving the anaesthetic efficacy of linalool EOAR (BALDISSEROTTO et al., 2018). Linalool obtained from the EO of $A$. rosaeodora $(80 \%$ S-(+) and 20\% R-(-) isomers) (BALDISSEROTTO et al., 2018) is slightly faster than EOLA-L at inducing the deep anesthesia of tambaqui, but the latter EO is more effective at inducing sedation than linalool since only $25 \mu \mathrm{L} / \mathrm{L}$ is necessary, compared to 100 $\mu \mathrm{L} / \mathrm{L}$ of linalool.
The time required to induce sedation with EOLO-Ca in tambaqui was similar to that reported for silver catfish, however the time required to induce deep anesthesia was longer (BECKER et al., 2018). The anesthetic effect of EOLO-Ca on silver catfish was similar to carvacrol, its main compound (BIANCHINI et al., 2017; BECKER et al., 2018). Recovery time of tambaqui from anesthesia with EOLO-Ca was much longer than that observed for silver catfish (BECKER et al., 2018).

The evaluation of the VF is an interesting parameter to understand the fish's physiological response to anesthetics (BECKER et al., 2012; TONI et al., 2014; BECKER et al., 2018). BECKER et al. (2012) and TONI et al. (2014) reported an increased VF in silver catfish a few minutes after exposure to anesthetics. This hyperventilation, associated with an increase in oxygen consumption at the beginning of anesthesia, is common (SUMMERFELT \& SMITH, 1990). Normally, after this initial period, the VF reduces considerably in the presence of the anesthetic (BECKER et al., 2012). Overall, in the present study, it was not possible to establish a direct relationship between increases in $\mathrm{EO}$ concentration and a reduction in VF, with the exception of the anesthesia stage with EOLA-C, in which a concentration of $200 \mu \mathrm{L} / \mathrm{L}$ led to a significantly lower VF than $25 \mu \mathrm{L} / \mathrm{L}$. However, in fish 
Table 2 - Effects of the essential oils of Lippia alba: EOLA-C (chemotype citral) and EOLA-L (chemotype linalool), and Lippia origanoides: EOLO-Ca (chemotype carvacrol) on the ventilatory frequency of tambaqui, Colossoma macropomum, in different anesthesia stages.

\begin{tabular}{|c|c|c|}
\hline \multirow{2}{*}{$\begin{array}{l}\text { Concentration }(\mu \mathrm{L} / \mathrm{L}) \\
\text { EOLA-C }\end{array}$} & \multicolumn{2}{|c|}{ 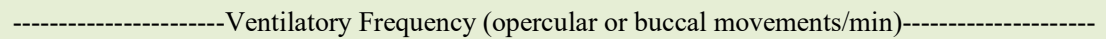 } \\
\hline & Sedation & Deep anesthesia \\
\hline 25 & $37.00 \pm 2.78^{\mathrm{ab}}$ & $50.70 \pm 3.09^{\mathrm{a}}$ \\
\hline 50 & $27.43 \pm 2.30^{\mathrm{b}}$ & $22.83 \pm 3.57^{\mathrm{c}}$ \\
\hline 100 & $35.83 \pm 3.36^{\mathrm{ab}}$ & $36.43 \pm 2.82^{b}$ \\
\hline 200 & $46.70 \pm 3.72^{\mathrm{a}}$ & $34.83 \pm 3.74^{\mathrm{b}}$ \\
\hline \multicolumn{3}{|l|}{ EOLA-L } \\
\hline 25 & $24.60 \pm 2.25^{\mathrm{a}}$ & $35.33 \pm 4.63^{\mathrm{a}}$ \\
\hline 50 & $18.86 \pm 2.07^{\mathrm{a}}$ & $28.20 \pm 3.02^{\mathrm{ab}}$ \\
\hline 100 & $25.80 \pm 1.85^{\mathrm{a}}$ & $17.67 \pm 1.58^{b}$ \\
\hline 200 & $29.20 \pm 3.93^{\mathrm{a}}$ & $21.86 \pm 2.89^{\mathrm{ab}}$ \\
\hline \multicolumn{3}{|l|}{ EOLO-Ca } \\
\hline 25 & $20.17 \pm 2.21^{\mathrm{b}}$ & $21.00 \pm 0.55^{\mathrm{ab}}$ \\
\hline 50 & $20.50 \pm 1.78^{b}$ & $15.25 \pm 1.77^{b}$ \\
\hline 100 & $18.57 \pm 2.12^{\mathrm{b}}$ & $20.43 \pm 2.41^{\mathrm{ab}}$ \\
\hline 200 & $34.80 \pm 3.01^{\mathrm{a}}$ & $27.67 \pm 3.41^{\mathrm{a}}$ \\
\hline
\end{tabular}

Values are mean \pm SEM. Different lowercase letters in the column indicate significant differences between concentrations at the same anesthesia stage $(\mathrm{P}<0.05)$.

sedated with EOLO-Ca, the VF was significantly higher at $200 \mu \mathrm{L} / \mathrm{L}$ than that at $25 \mu \mathrm{L} / \mathrm{L}$. Recently, BECKER et al. (2018) did not find large differences in the VF of silver catfish exposed to EOLA-C or EOLO-Ca compared to the control group. Interestingly, TONI et al. (2014) reported lower VF values in silver catfish sedated with $450 \mu \mathrm{L} / \mathrm{L}$ EO of Hesperozygis ringens or EOLA-L compared to the other EO concentrations. Therefore, it is very difficult to establish a general response in terms of an increase or decrease in the VF as a function of the EO concentration; thus, this process might best be understood as a species-specific response.

Taking all results together, EOLO-Ca showed the shortest times to induce sedation and anesthesia, but the recovery times were longer. Therefore, the recommended EOs for tambaqui are EOLA-C and EOLA-L, with efficient sedation, anesthesia, and recovery times at 100 and $200 \mu \mathrm{l} / \mathrm{L}$, respectively.

\section{ACKNOWLEDGEMENTS}

The authors are grateful to Dr. Fátima Salimena and Dr. Gilberto Dolejal Zanetti for the identification of $L$. alba and $L$. origanoides. This study was supported by INCT-ADAPTA 2 and Fundação de Amparo à Pesquisa do Estado do Rio Grande do Sul (FAPERGS/PRONEX, process 10/0016-8). B Baldisserotto and BM Heinzmann were recipients of Conselho Nacional de Pesquisa e Desenvolvimento Científico (CNPq, Brazil) research fellowships and HNP Silva, JLS Maia, BCF Carvalho and AG Becker received $\mathrm{MSc}$ and $\mathrm{PhD}$ fellowships from Coordenação de Aperfeiçoamento de Pessoal de Nível Superior (CAPES, Brazil).

\section{BIOETHICS \\ AND \\ COMMITTEE APPROVAL}

BIOSSECURITY

This research was approved by the Ethical Committee of Pará State University - Brazil, under registration no. 042-2012.

\section{DECLARATION OF CONFLICT OF INTERESTS}

The authors declare no conflict of interest. The founding sponsors had no role in the design of the study; in the collection, analyses, or interpretation of data; in the writing of the manuscript, and in the decision to publish the results.

\section{AUTHORS' CONTRIBUTIONS}

All authors contributed equally for the conception and writing of the manuscript. All authors critically revised the manuscript and approved of the final version.

\section{REFERENCES}

ALVARENGA, C.M.D.; VOLPATO, G.L. Agonistic profile and metabolism in alevins of the Nile tilapia. Physiology \& Behavior, v.57: p.75-80, 1995. Available from: <http://www.sciencedirect. com/science/article/pii/003193849400206K>. Accessed: Jan. 19, 2018. doi: 10.1016/0031-9384(94)00206-K.

Ciência Rural, v.49, n.6, 2019. 
BALDISSEROTTO, B. et al. Anesthesia of tambaqui Colossoma macropomum (Characiformes: Serrasalmidae) with the essential oils of Aniba rosaeodora and Aniba parviflora and their major compound, linalool. Neotropical Ichthyology, v.16: 2018. Available from: <http://www.scielo.br/scielo.php?script=sci arttext\&pid=S1679-62252018000100215\&nrm=iso>. Accessed: Aug. 27, 2018. doi: 10.1590/1982-0224-20170128.

BATISTA, E.S. et al. Lippia alba essential oil as anesthetic for tambaqui. Aquaculture, v.495: p.545-549, 2018. Available from: <http:// www.sciencedirect.com/science/article/pii/S0044848618306690>. Accessed: Aug. 27, 2018. doi: 10.1016/j.aquaculture.2018.06.040.

BECKER, A.G. et al. Transportation of silver catfish, Rhamdia quelen, in water with eugenol and the essential oil of Lippia alba. Fish Physiology and Biochemistry, v.38: p.789-796, 2012. Available from: <http://dx.doi.org/10.1007/s10695-011-9562-4>. Accessed: Sep. 28, 2018. doi: 10.1007/s10695-011-9562-4

BECKER, A.J. et al. Ventilatory frequency and anesthetic efficacy in silver catfish, Rhamdia quelen: a comparative approach among different essential oils, Revista Brasileira de Zootecnia, v.47: 2018. Available from: $<$ http://www.scielo.br/scielo.php?script $=$ sci arttext\&pid $=\mathrm{S} 1516-35982018000100105 \& \mathrm{nrm}=\mathrm{iso}>$. Accessed: Dec. 21 , 2018. doi: 10.1590/rbz4720170185.

BIANCHINI, A.E. et al. Monoterpenoids (thymol, carvacrol and S-(+)-linalool) with anesthetic activity in silver catfish (Rhamdia quelen): evaluation of acetylcholinesterase and GABAergic activity. Brazilian Journal of Medical and Biological Research, v.50: 2017. Available from: $<$ http://www.scielo.br/scielo.php?script $=$ sci arttext\&pid=S0100-879X2017001200610\&nrm=iso $>$. Accessed: Sep. 24, 2018. doi: 10.1590/1414-431x20176346.

CASTRO, D.M. et al. Composition of the essential oils of Lippia alba (Mill.) N. E. Br. at different times of harvest and different part of the branch. Revista Brasileira de Plantas Medicinais, v.4: p.7579, 2002. Available from: <http://hdl.handle.net/11449/66784> Accessed: Apr. 01, 2019.

CUNHA, M.A. et al. Essential oil of Lippia alba: A new anesthetic for silver catfish, Rhamdia quelen. Aquaculture, v.306: p.403-406, 2010. Available from: <http://www.sciencedirect.com/science/ article/pii/S0044848610003790>. Accessed: Sep. 28, 2018. doi: 10.1016/j.aquaculture.2010.06.014

HELDWEIN, C.G. et al. Participation of the GABAergic system in the anesthetic effect of Lippia alba (Mill.) N.E. Brown essential oil. Brazilian Journal of Medical and Biological Research, v.45: p.436-443, 2012. Available from: <http:// www.scielo.br/scielo.php?script $=$ sci_arttext\&pid $=\mathrm{S} 0100$ $879 X 2012000500009 \& n r m=$ iso $>$. Accessed: Feb. 29, 2016. doi: $10.1590 / \mathrm{S} 0100-879 \times 2012007500052$.

HENNEBELLE, T. et al. Ethnopharmacology of Lippia alba. Journal of Ethnopharmacology, v.116: p.211-222, 2008. Available from: $<\mathrm{http} / /$ www.sciencedirect.com/science/article/pii/S0378874107006447>. Accessed: Sep. 24, 2018. doi: 10.1016/j.jep.2007.11.044.

HOHLENWERGER, J.C. et al. Could the essential oil of Lippia alba provide a readily available and cost-effective anaesthetic for Nile tilapia (Oreochromis niloticus)? Marine and Freshwater Behaviour and Physiology, p.1-8, 2016. Available from: $<$ https://www.tandfonline.com/doi/abs/10.1080/10236244.2015 .1123869 ? journalCode $=$ gmfw20 $>$. Accessed: Sep. 28, 2018. doi: $10.1080 / 10236244.2015 .1123869$
JULIÃO, L.S. et al. Thin layer chromatography of extracts of three chemotypes Lippia alba (Mill) N.E.Br. (erva-cidreira). Revista Brasileira de Farmacognosia, v.13: p.36-38, 2003. Available from: $<$ http://www.scielo.br/scielo.php?script=sci arttext\&pid=S0102-695X2003000300014\&nrm=iso>. Accessed: Sep.17, 2018. doi: 10.1590/S0102-695X2003000300014.

RIBEIRO, S.M. et al. Influence of seasonality and circadian cycle yield and chemical composition of essential oils of Croton spp. Caatinga. Iheringia Série Botânica, v.73: p.31-38, 2018. Available from: <https://isb.emnuvens.com.br/iheringia/article/view/371/428>. Accessed: Apr. 01, 2019. doi: 10.21826/2446-8231201873104.

SACCOL, E.M.H. et al. Anaesthetic and antioxidant effects of Myrcia sylvatica (G. Mey.) DC. and Curcuma longa L. essential oils on tambaqui (Colossoma macropomum). Aquaculture Research, v.48: p.2012-2031, 2017. Available from: <https://onlinelibrary.wiley.com/doi/abs/10.1111/ are.13034>. Accessed: Aug. 27, 2018. doi: 10.1111/are.13034.

SANTOS, G.M.D. et al. Peixes comerciais de Manaus. ManausAM: IBAMA, 2009. 144p.

SENA, A.C. et al. Essential oil from Lippia alba has anaesthetic activity and is effective in reducing handling and transport stress in tambacu (Piaractus mesopotamicus $\times$ Colossoma macropomum). Aquaculture, v.465: p.374-379, 2016. Available from: <http:// www.sciencedirect.com/science/article/pii/S004484861630494X>. Accessed: Sep. 24, 2018. doi: 10.1016/j.aquaculture.2016.09.033.

SILVA, H.N.P. et al. Lippia alba (Verbenaceae) hydrolate as sedative of tambaqui (Colossoma macropomum) juveniles in simulated transport conditions. Aquaculture Research, 2017. Available from: < https://onlinelibrary.wiley.com/doi/abs/10.1111/ are.13441>. Accessed: Jul. 12, 2017. doi: 10.1111/are.13441.

SOARES, B.V. et al. Antiparasitic, physiological and histological effects of the essential oil of Lippia origanoides (Verbenaceae) in native freshwater fish Colossoma macropomum. Aquaculture, v.469: p.72-78, 2017. Available from: <http://www.sciencedirect. com/science/article/pii/S0044848616307852>. Accessed: Sep. 14, 2018. doi: 10.1016/j.aquaculture.2016.12.001.

SOUZA, C.F. et al. Citral and linalool chemotypes of Lippia alba essential oil as anesthetics for fish: a detailed physiological analysis of side effects during anesthetic recovery in silver catfish (Rhamdia quelem). Fish Physiology and Biochemistry, v.44: p.21-34, 2018. Available from: <https://doi.org/10.1007/s10695-017-0410-z>. Accessed: Sep. 14, 2018. doi: 10.1007/s10695-017-0410-z.

STASHENKO, E.E. etal.Lippia origanoides chemotype differentiation based on essential oil GC-MS and principal component analysis. Journal of Separation Science, v.33: p.93-103, 2010. Avaliable from: $<$ https://onlinelibrary.wiley.com/doi/abs/10.1002/jssc.200900452>. Accessed: Sep. 17, 2018. doi: 10.1002/jssc.200900452.

SUMMERFELT, R.C.; SMITH, L.S. Anesthesia, surgery, and related techniques. In: SCHRECK, C. B. \& MOYLE, P. B. Methods for fish biology. Bethseda, Maryland-USA: American Fish Society, 1990. p.213-272.

TONI, C. et al. Fish anesthesia: effects of the essential oils of Hesperozygis ringens and Lippia alba on the biochemistry and physiology of silver catfish (Rhamdia quelen). Fish Physiology and Biochemistry, v.40: p.701-714, 2014. Available from: $<$ http:// dx.doi.org/10.1007/s10695-013-9877-4>. Accessed: Sep. 28, 2018. doi: 10.1007/s10695-013-9877-4. 